\title{
Is the price elasticity of demand for coal in China increasing?
}

\section{CCEP Working Paper 1506 June 2015}

\section{Paul J. Burke}

Crawford School of Public Policy, The Australian National University

\section{Hua Liao}

School of Management and Economics, Beijing Institute of Technology

\begin{abstract}
China's dependence on coal is a major contributor to local and global environmental problems. In this paper we estimate the price elasticity of demand for coal in China using a panel of province-level data for the period 1998-2012. We find evidence that provincial coal demand has become increasingly price elastic. As of 2012 we estimate that this elasticity was in the range -0.3 to -0.7 when responses over two years are considered. The results imply that China's coal market is becoming more suited to price-based approaches to reducing emissions. Our estimates suggest that the elimination of coal consumption subsidies could reduce national coal use and related emissions by around $2 \%$.
\end{abstract}




\section{Keywords:}

Coal; price elasticity; demand; China; provincial

\section{JEL Classification:}

O13, Q41, P28, Q48

\section{Suggested Citation:}

Burke, P.J. and Liao, H. (2015), Is the price elasticity of demand for coal in China increasing?, CCEP Working Paper 1506, June 2015. Crawford School of Public Policy, The Australian National University.

\section{Address for Correspondence:}

Paul J. Burke

Fellow

Arndt-Corden Department of Economics

Crawford School of Public Policy

The Australian National University

ACT 2601

Australia

Tel: +61261256566

Email: paul.j.burke@anu.edu.au

The Crawford School of Public Policy is the Australian National University's public policy school, serving and influencing Australia, Asia and the Pacific through advanced policy research, graduate and executive education, and policy impact.

The Centre for Climate Economics \& Policy is an organized research unit at the Crawford School of Public Policy, The Australian National University. The working paper series is intended to facilitate academic and policy discussion, and the views expressed in working papers are those of the authors. Contact for the Centre: Dr Frank Jotzo, frank.jotzo@anu.edu.au 


\section{Is the price elasticity of demand for coal in China increasing?}

Paul J. Burke ${ }^{a, *}$ and Hua Liao ${ }^{\text {b, c }}$

a Arndt-Corden Department of Economics, Australian National University, Canberra, ACT 2601, Australia

${ }^{\mathrm{b}}$ School of Management and Economics, Beijing Institute of Technology, Beijing 100081, China

${ }^{c}$ Center for Energy and Environmental Policy Research, Beijing Institute of Technology, Beijing 100081, China

* Corresponding author. E-mail: paul.j.burke@anu.edu.au. Telephone: +61 261256566

5 June 2015

China's dependence on coal is a major contributor to local and global environmental problems. In this paper we estimate the price elasticity of demand for coal in China using a panel of province-level data for the period 1998-2012. We find evidence that provincial coal demand has become increasingly price elastic. As of 2012 we estimate that this elasticity was in the range -0.3 to -0.7 when responses over two years are considered. The results imply that China's coal market is becoming more suited to price-based approaches to reducing emissions. Our estimates suggest that the elimination of coal consumption subsidies could reduce national coal use and related emissions by around $2 \%$.

Keywords: coal, price elasticity, demand, China, provincial

JEL classification: O13, Q41, P28, Q48

Acknowledgements: We are grateful for comments from two reviewers, Ryan Edwards, Frank Jotzo, and participants at several presentations in China and Australia. The research received funding from the Australia-China Research Program on Climate Change Mitigation Policy, the CAS Strategic Priority Research Program (No. XDA05150600), and the National Natural Science Foundation of China (No. 71322306, 71273027). 


\section{Introduction}

China accounts for half of global coal consumption, and the International Energy Agency (IEA, 2014a) expects this share to remain quite stable over the next several decades under current policies. The country's coal use is a substantial contributor to local and regional environmental problems, accounting for more than one-fifth of annual global carbon dioxide $\left(\mathrm{CO}_{2}\right)$ emissions from all energy sources (IEA, 2014b). China is currently trialling carbon pricing schemes in an effort to reduce greenhouse gas emissions. Yet relatively little recent evidence exists on how responsive China's coal demand is to coal prices, and whether this responsiveness has changed over time. Evidence using sub-national data is particularly scarce.

In this paper we use data on provincial coal prices and coal use to estimate the price elasticity of demand for coal in China. We construct a panel covering 30 provincial-level divisions (“provinces") for the 15-year period 1998-2012, and control for province fixed effects and other factors possibly affecting coal demand. We use sample splitting and interaction terms to explore whether the price elasticity of coal demand has changed over time. Our results suggest that provincial coal demand is becoming increasingly price sensitive, and as of 2012 was in the order of -0.3 to -0.7 when responses over a period of two years are considered. China's economy and coal sector have marketized over recent decades, a process that may have contributed to the increasing price elasticity of demand as prices gradually take on a greater role in rationing China's coal consumption. The paper adds to a growing body of literature using provincial-level data on energy use in China (e.g. Cattaneo et al., 2011; Du et al., 2012; Ma and Oxley, 2012).

Coal is not a homogenous commodity. The metallurgic industry mainly uses coking coal, whereas electricity generators use thermal coal, for instance. Within any broad classification there is substantial variation in coal grades and types, and in the prices for these products. While the price elasticity of coal demand may vary for different types and uses of coal, data restrictions mean that we focus on total provincial coal use, aggregated in tonnes. An advantage of adopting a panel approach is that we can control for some unobserved characteristics of coal consumption, including the average quality of the coal consumed in each province. 
Our finding that China's provincial-level coal price elasticity of demand is increasing is new, and has several implications. One is that price-based approaches to reducing the environmental impacts of coal use are becoming increasingly relevant in the China context. This paper's results are also useful for informing parameter choices in energy models. ${ }^{1} \mathrm{We}$ also estimate the reduction in coal use and related emissions that would result from a phaseout of coal consumption subsidies in China.

The paper is organized as follows. Section 2 provides an overview of China's coal sector, including a brief history of its ongoing marketization. Section 3 discusses our method, and Section 4 describes our data. Section 5 presents our results, and we compare our estimates to earlier studies in Section 6. The final section concludes.

\section{China's coal sector}

\subsection{China's coal use and emissions}

China's appetite for coal has grown at an extraordinary rate. Figure 1 shows annual coal use in China and the rest of the world for 1965-2013 (aggregated in energy content terms). In 1965 , China accounted for only $8 \%$ of global coal consumption. Over the 48 years to 2013 , China's coal use increased at an average of $6.1 \%$ per annum. This growth saw China's share of global coal consumption exceed 50\% in 2013 for the first time in modern history (based on the data from BP, 2014). Coal use in the rest of the world has grown more slowly, averaging 0.8\% per year over 1965-2013. China's growth in coal use is perhaps coming to a turning point, however: in a historic change, China's coal consumption was recorded as having fallen in 2014 (data not shown; Reuters, 2015).

\footnotetext{
${ }^{1}$ See Mischke and Karlsson (2014) for a recent review of models of China's energyeconomic system.
} 


\section{Figure 1}

Coal consumption by China and the rest of the world, 1965-2013.

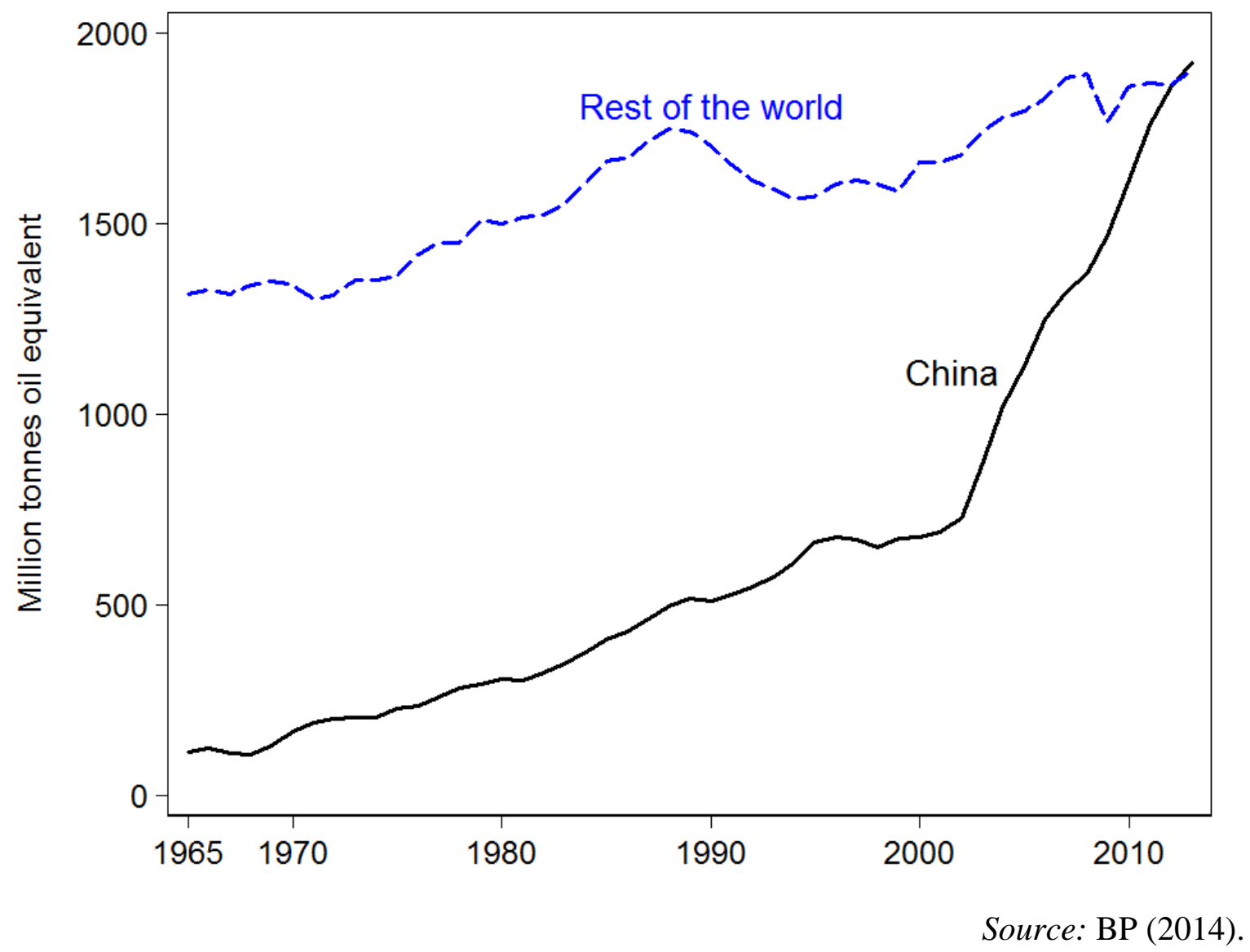

The most rapidly growing use of coal in China over our study period has been for electricity generation. Figure 2 shows data on primary coal consumption by China's electricity, manufacturing, and other sectors for the period 1994-2012. As of 2012 electricity generation accounted for half of all coal use in China, with manufacturing directly consuming $38 \%$. Coal-fired electricity output expanded at an average annual rate of $9.3 \%$ over the period 1971-2012. In 2012, 76\% of China's electricity generation was coal-fired, up from $70 \%$ in 1971 (IEA, 2015). Residential coal consumption, included in the "Other" category in Figure 2 , has fallen as a result of factors such as the installation of central heating systems and electrification. China's rapid rise has involved a huge expansion of energy-hungry sectors such as the steel industry, the output of which has increased more than 30 -fold over the last four decades (CEIC, 2014). 
Figure 2

Primary coal consumption by sector, 1994-2012.

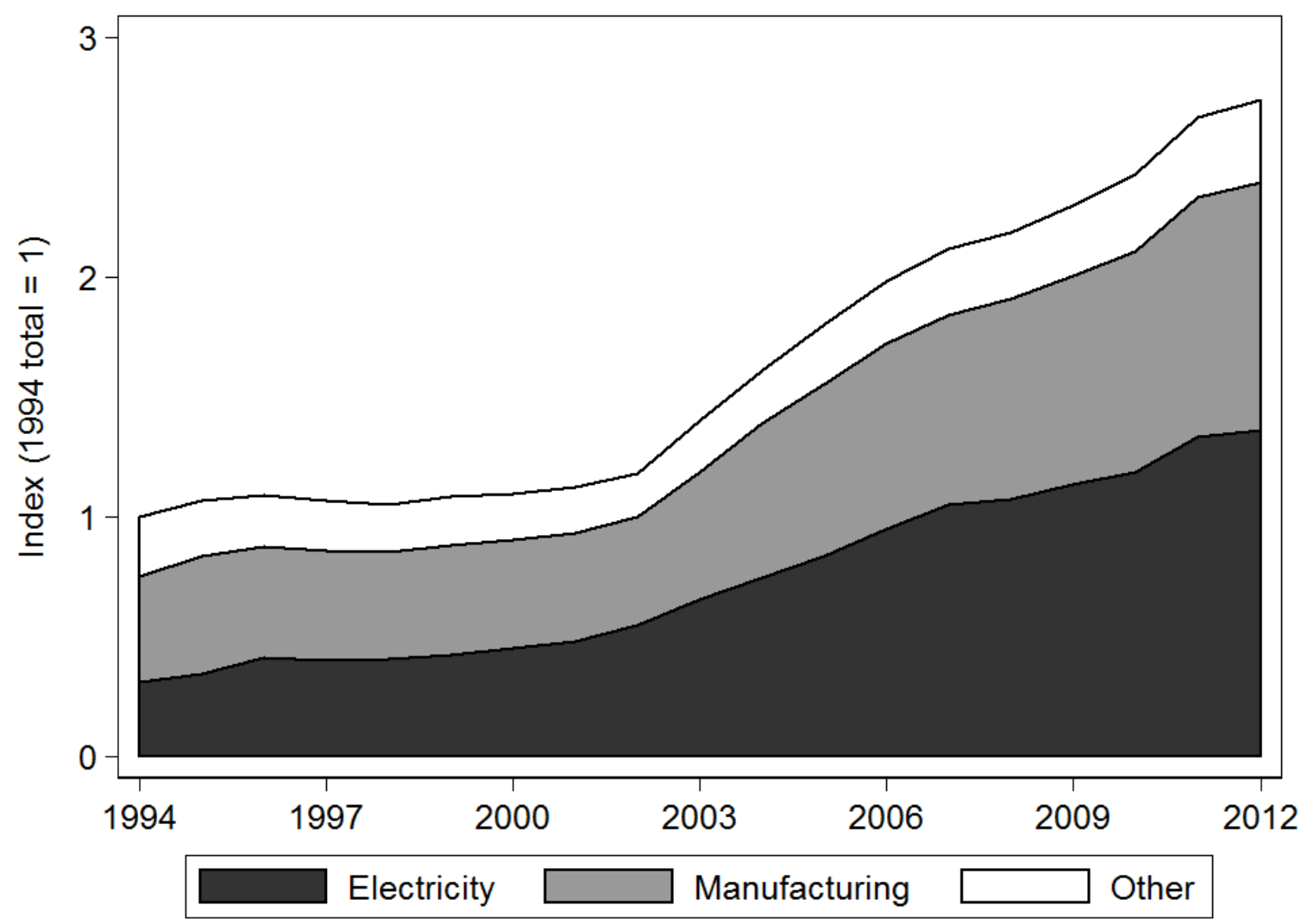

Notes: "Electricity" also includes coal used by the water and gas sectors. Data are aggregated in tonnes rather than an energy-equivalent unit. Source: CEIC (2014).

Coal dominates China's $\mathrm{CO}_{2}$ emissions profile. Figure 3 shows China's total energy-based $\mathrm{CO}_{2}$ emissions by fuel for the years 1971-2012. In 2012 83\% of China's energy-based $\mathrm{CO}_{2}$ emissions were from coal, a share that has remained quite steady since the early 1970 s. $14 \%$ of China's energy-based emissions were from oil, and only $3 \%$ from natural gas. Coal is also the primary contributor of other atmospheric emissions in China, including sulphur dioxide and particulates, and so has large health implications. Outdoor air pollution, mostly from coal, has been estimated as causing around 1.2 million deaths per year nationally (Wong, 2013). 


\section{Figure 3}

China's $\mathrm{CO}_{2}$ emissions from energy use by fuel, 1971-2012.

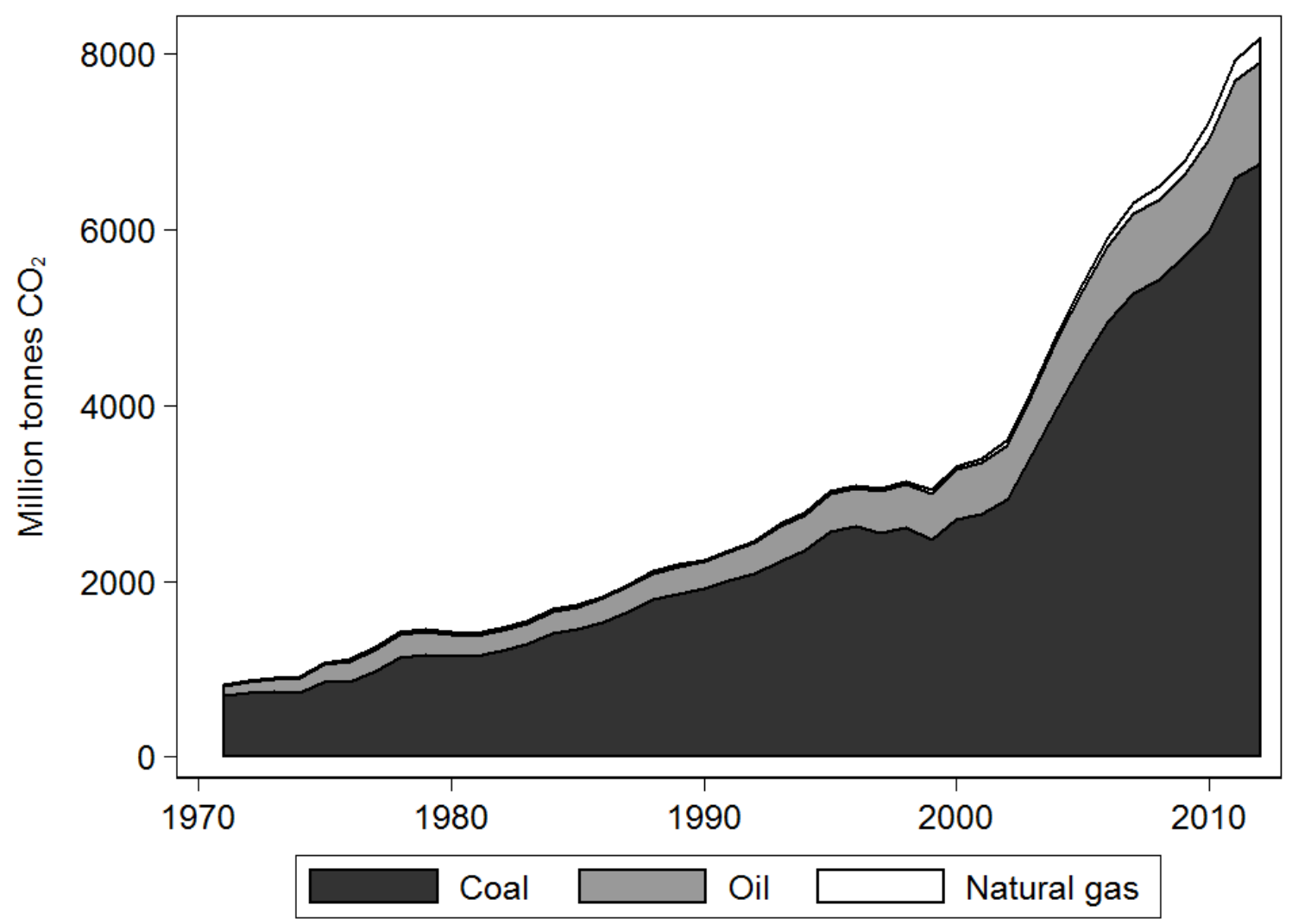

Source: IEA (2014b).

Figure 4 presents China's output price index for the mining and washing of coal, the coal price measure we use at the provincial level in our empirical estimations. The index almost tripled over the first decade of the new millennium in nominal terms, before falling in 2012 (the last year of our empirical analysis). Coal price increases outstripped the modest increases in China's aggregate industrial producer price index, meaning that in real terms coal prices more than doubled over the decade. The 2012 downturn in the coal price index extended into 2013, a year for which nominal coal prices were recorded as falling by around $11 \%$. Figure 4 also shows a coal import price at Qinhuangdao port, China's largest coal shipping port. The Qinhuangdao price is positively correlated with the coal sector's output price index, but displays greater volatility. 


\section{Figure 4}

Nominal coal price index and industrial producer price index for China, 1998-2013.

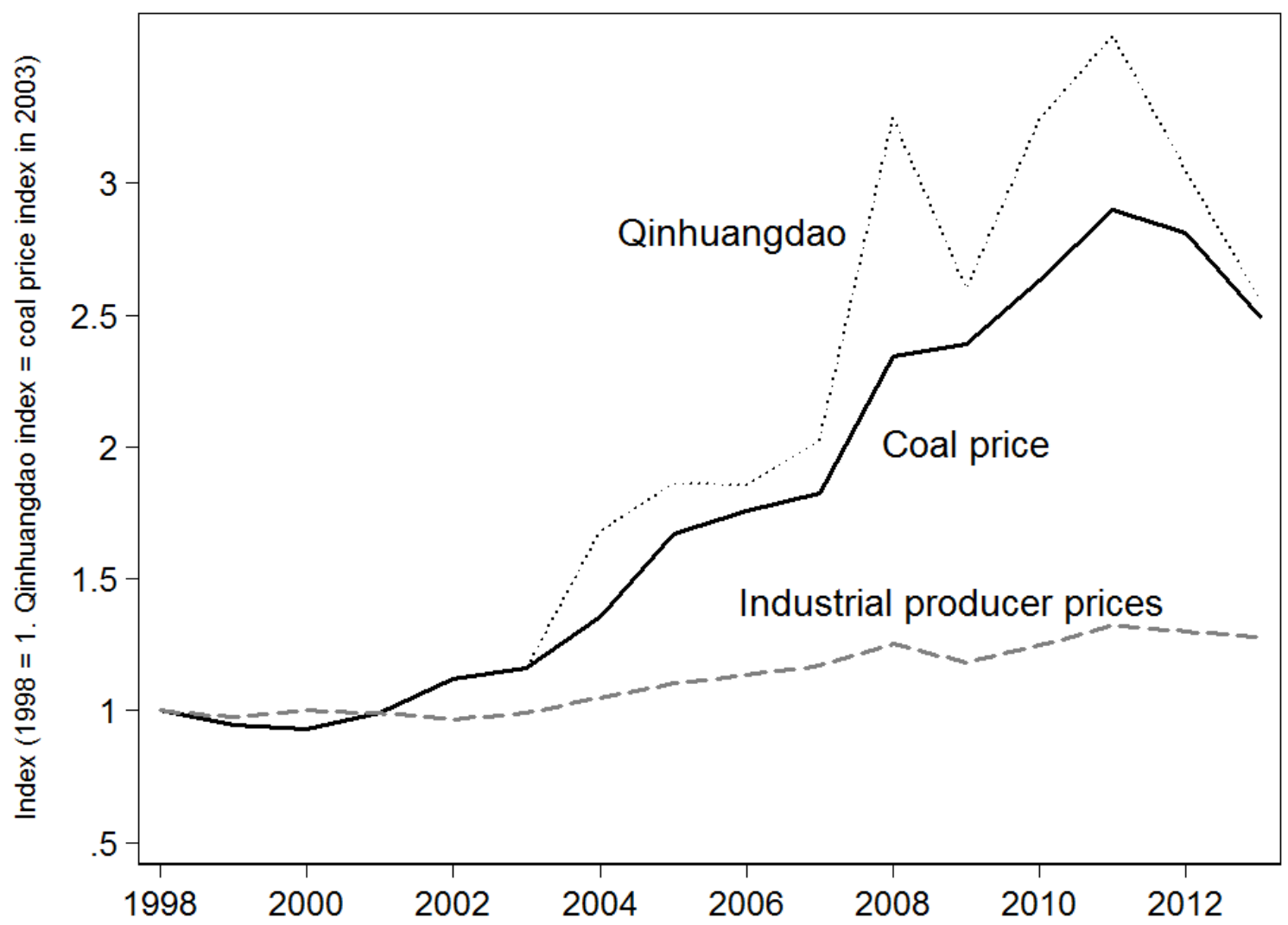

Notes: The coal price index is the nominal output price index for the mining and washing of coal. This is the same index we use at the provincial level in our statistical analysis (in logged deflated form). Source: National Bureau of Statistics (2014). The Figure also shows a nominal Qinhuangdao import price index for 2003-2013. The index, set equal to the coal price index in 2003, measures the free on board (FOB) price for steam coal imports (Q5500K). Source: Wind Information (2015).

China's substantial geographical variation in per-capita coal use is shown in Figure 5. The highest reliance on coal is in China's north, where the largest coal reserves and a large share the country's heavy industry can be found. Southern provinces are smaller users of coal. Our method addresses persistent differences in coal dependence via the use of province fixed effects and estimates in differences. 


\section{Figure 5}

Map of coal consumption per capita (tonnes) by province, 2012.

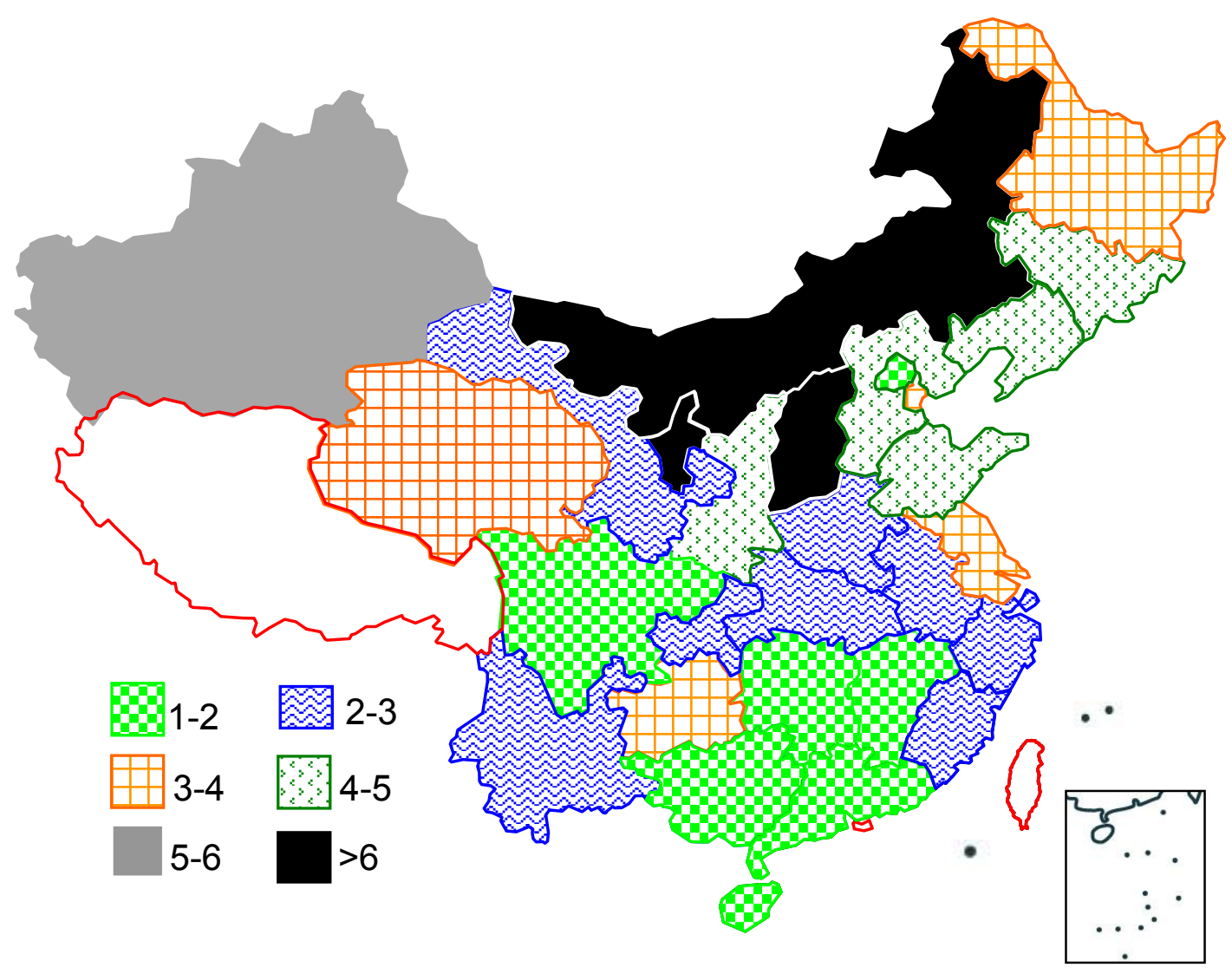

Notes: This is a schematic and does not identify definite boundaries. Data for Tibet are not available.

\subsection{Marketization of China's coal sector}

The ongoing marketization of China's coal sector as the country continues its transition from a planned to a more market-based economy might be expected to increase the price elasticity of coal demand, as prices have gradually played a more important role in rationing coal use. In this section we provide details about the marketization process.

During 1949-1978, the production, transportation, and use of coal and other "strategic resources" were primarily allocated by the central government, and coal prices were maintained at a low level (Thomson, 2003; Xiao and Wu, 2011; Wright, 2000, 2012). In 1978, China began its policies of reform and opening-up. In the subsequent years, coal continued to be priced and allocated by the government, but prices and the profit mechanism began to play a more substantial role in resource allocation. 
An important step occurred in 1984-1985 with the official introduction of a "dual track" pricing system with separate in-plan and out-plan prices for coal and other commodities (Wright, 2000; Wang, 2007; Yang et al., 2012). A share of coal was still mandatorily priced by the government, but the remainder was able to be priced by the market. A large share of the coal produced by local township enterprises was not included in the national plan and so was priced freely. Noticeable regional price differences emerged.

In late 1993 the central government announced that coal price regulation would be abolished. While the move to market-based pricing for non-electricity consumers of coal was largely successful, electricity generators faced problems in adjusting to market prices for coal given that they continued to face tightly regulated electricity prices. In 1996 the central government returned to its role of controlling the price of a large share of the coal sold to electricity generators, with prices for "key contract" coal usually 10-30\% below the market price (Wang, 2007; Yue, 2007; Ma et al., 2009; Ma and Oxley, 2012; Wright, 2012). Various government interventions to influence coal prices for the electricity sector were used, including price caps and price guidance during contract negotiations.

Since 1996, China's government has made numerous attempts to finally end its influence over coal prices for electricity generators. Yet the reform path has been tortuous: disagreements between the coal and electricity sectors and the threat of electricity shortages have repeatedly forced the government to continue in the role, albeit for contracts representing a generally diminishing share of coal sales (China Daily, 2007; IEA, 2009; Li, 2014).

While there has been continued central influence over coal prices for the electricity sector, it is important to note that even government-influenced coal prices are affected by market movements: they rise when supply constraints are pressing, for example (Chu et al., 2006). Compliance with government controls has also not been complete, with strategies for avoiding the trappings of low-price coal supply contracts including the levying of additional fees; supplying low-quality coal; and simply not delivering, thereby forcing electricity generators to purchase coal on the spot market (Rutkowski, 2013). There is evidence that coal and electricity prices have started to co-move (Ma and Oxley, 2011), suggesting increasing influence of market forces. 
At the end of 2007, the National Development and Reform Commission released a new Coal Industrial Policy (Zhao et al., 2012), and the coal sector has reached a new level of marketization which, while not complete, involves a greater role for market forces in allocating coal than has historically been the case (Ma and Oxley, 2012). Nevertheless, the central government has still intervened, for example by ordering a freeze on coal prices for electricity companies in 2011 to quell inflation (The Economist, 2011). As of 2012 a share of the coal supplied to electricity generators was still under government-guided contracts with below-market prices (Zhang, 2012), with the IEA (2013) estimating that coal and electricity consumption subsidies equalled $\$ 13$ billion per annum. ${ }^{2}$

In late 2012 it was again announced that the central government would no longer require coal producers to enter into contracts to supply quantities of "key contract" coal to electricity generators at preferential prices (Zhang, 2014). In November 2013 a blueprint for the reform was released. Time is needed to evaluate how this latest iteration of reform is executed. In short, the general trend has been to an increasing marketization of coal sales to the electricity sector, and it is fair to say that coal sales outside the electricity sector are quite highly marketized.

\section{Method}

To obtain estimates of the average price elasticity of demand for coal at the provincial level in China, we start with a basic log-log demand model:

$\ln C_{p, t}=\beta_{1} \ln P_{p, t}+\beta_{2} \ln Y_{p, t}+\beta_{3} t+\delta_{p}+\varepsilon_{p, t}$

where $C$ is primary coal consumption in province $p$ in year $t, P$ is an output price index for the mining and washing of coal deflated by the industrial producer price index, $Y$ is GDP, $t$ is a linear time trend ranging from 0 in 1998 to 14 in 2012, $\delta_{p}$ is province fixed effects, $\varepsilon$ is an error term, and $\ln$ is the natural logarithm. Our use of data on coal consumption, not production, is appropriate for a study of demand (cf. supply). We include province fixed effects to control for time-invariant factors that may influence coal demand in each province. The choice of fixed effects over random effects is supported by a Hausman test. As a robustness check we will also present results using random effects estimation. Results tables

\footnotetext{
${ }^{2}$ The electricity subsidies largely result from low-price coal, so we include these in our analysis.
} 
will employ standard errors that are robust to heteroskedasticity and clustered at the province level to allow for province-specific patterns of serial correlation.

Eq. (1) is a static estimation using within-province temporal variation. This approach is typically interpreted as providing short-run elasticities (Baltagi, 2008). To capture the fact that adjustments to changes in coal prices take time and that coal contracts often extend over more than one calendar year, we also present estimations including lagged coal price terms. We use lags for years $t-1$ and $t-2$. To conserve degrees of freedom, we then move to specifications that include only the terms for year $t$ and year $t-2$, as the $t-1$ lagged price term is not statistically significant. Using the $3^{\text {rd }}$ or $4^{\text {th }}$ lags provides similar results to using the $2^{\text {nd }}$ lag, but further reduces sample size.

Our primary interest is whether the coal price elasticity of demand has changed over time. We hypothesize that coal demand has become more price elastic, in part as a result of the increasing role of prices and market forces in rationing coal use in China. If prices were previously less important in coal use decisions than they are now, we would expect this to be reflected in $\beta_{2}$ being less negative for earlier years of our sample than later years. This hypothesis appears to have yet to be tested using provincial panel data.

We use two approaches to carry out such a test. The first is splitting the sample into an "early" period (1998-2007) and a "late" period, which we define as 2008-2012, years during which the coal sector has exhibited its highest level of marketization to date (Ma and Oxley, 2012, p. 139). We obtain similar results if we define the "late" period as commencing in 2009 or $2010 .{ }^{3}$ Our second and more flexible approach is to estimate specifications that interact our coal price terms with the time trend in both the static estimations and the estimations with the lagged price term:

$$
\begin{aligned}
& \ln C_{p, t}=\beta_{1} \ln P_{p, t}+\beta_{2} \ln Y_{p, t}+\beta_{3} t+\beta_{4} \ln P_{p, t} * t+\delta_{p}+\varepsilon_{p, t} \\
& \ln C_{p, t}=\beta_{1} \ln P_{p, t}+\beta_{2} \ln Y_{p, t}+\beta_{3} t+\beta_{4} \ln P_{p, t} * t+\beta_{5} \ln P_{p, t-2}+\beta_{6} \ln P_{p, t-2} * t+\delta_{p}+\varepsilon_{p, t}
\end{aligned}
$$

\footnotetext{
${ }^{3}$ Our price elasticity of coal demand for the "late" period becomes statistically indistinguishable from zero if we extend this period back to 2007. This is the principal result of the paper: we only find statistical evidence that the price elasticity of demand is negative for more recent years.
} 
In Eq. (2), the static price elasticity in the final year of our sample $(2012 ; t=14)$ is equal to $\beta_{1}$ $+14 \beta_{4}$. In Eq. (3), the two-year price elasticity in 2012 is equal to $\beta_{1}+\beta_{5}+14\left(\beta_{4}+\beta_{6}\right)$. Our tables will report these elasticities and their significance levels.

In additional specifications, we control for a set of time-varying factors that might influence provincial coal use. The first is the share of provincial output contributed by the secondary sector, as industrial output is likely to have a more coal-intensive input matrix. The second is the importance of state-owned enterprises in provincial economies. The third is a measure of the five-year energy conservation assignments prescribed to industrial enterprises in each province under the central Government's 1,000 Enterprises Energy Conservation Campaign of 2006-2010 and 10,000 Enterprises Energy Conservation Campaign of 2011-2015. The fourth is a measure of retired thermal power capacity, to capture the central government's campaign to phase out inefficient coal-fired electricity generation plants. We also control for each province's log real gasoline price.

In a check on our results, we also employ the following specification in differences:

$\Delta_{x \text {-year }} \ln C_{p, t}=\gamma_{0}+\gamma_{1} \Delta_{x \text {-year }} \ln P_{p, t}+\gamma_{2} \Delta_{x \text {-year }} \ln y_{p, t}+\gamma_{3} t+\gamma_{4} \Delta_{x \text {-year }} \ln P_{p, t} * t+\varepsilon_{p, t}$

where $\gamma_{2}+14 \gamma_{4}$ provides an estimate of the $x$-year price elasticity of provincial demand for coal, evaluated in 2012. This specification allows level effects to be removed, provides an efficient estimation of effects over more than one year, and avoids unit root issues (see below).

The potential endogeneity of coal prices is a concern: there may be reverse causality from demand to prices, or variables that are correlated with provincial coal prices may lurk in the error terms of our models. If this is the case, our estimates of the coal price elasticity of demand may be biased and inconsistent, with the direction of bias likely leading to an underestimate of the coal price elasticity (upward bias). We tried two instruments for our coal price index: 1) the log real international coal price, and 2) provincial coal reserves. Both, however, provided inadequate first-stage identification strength. ${ }^{4}$ Prior studies on China's coal demand have also not used instrumental variable approaches.

\footnotetext{
${ }^{4}$ The log international coal price remained a weak instrument even when weighted by each province's distance to the nearest sea port or the railway freight costs from the nearest sea
} 
Several factors help us to mitigate concerns regarding endogeneity. First, our use of the second lag of $\ln P$ reduces reverse causality from coal consumption to the coal price. ${ }^{5}$ Second, producer prices for coal may be relatively unaffected by provincial demand given that there are many external destinations for coal extracted in any province. Third, recent studies by Burke and Nishitateno (2013) and Lin and Zeng (2013) find that endogeneity bias is not substantial in studies estimating price elasticities of gasoline demand, although this is not necessarily generalizable to coal. Finally, our specifications consider a variety of controls, including provincial fixed effects (which take into account time-invariant sources of endogeneity). We obtain similar results across our estimations, pointing to a consistent story. Our use of a broad suite of time-varying controls and our treatment of time-invariant factors that may influence coal demand place this among the most rigorous studies to date on the coal price elasticity of demand in China.

An additional issue is the time-series properties of the data. Employing the panel unit root test of Im et al. (2003) with a time trend and the subtraction of cross-sectional means, we are able to reject the null hypotheses of unit roots in all provinces for the log coal consumption and $\log$ coal price index series. This test is suited to unbalanced panels such as ours. We are not able to reject the null that all provinces have a unit root in log GDP. Nevertheless, our results are similar in specifications that exclude log GDP. We also find similar results using differenced data (see Table 4). The Im et al. (2003) test rejects the nulls that all provinces have a unit root for first-year differenced data for log coal consumption, the log coal price index, and log GDP. Time-series issues are therefore not likely to be materially affecting our findings.

\section{Data}

Our estimations use yearly provincial panel data for the period 1998-2012, with our panel covering 30 provincial-level divisions in Mainland China: 22 (formal) provinces, 4 municipalities (Beijing, Tianjin, Shanghai, and Chongqing), and 4 autonomous regions (Inner Mongolia, Guangxi, Ningxia, and Xinjiang). Data on coal consumption are not available for

port. Province fixed effects, log GDP, and the time trend were included in these specifications. Several measures of international coal prices were explored.

${ }^{5}$ We obtain similar estimates in specifications that exclude the contemporaneous price term (i.e. use only the second lag). 
Tibet, so Tibet is excluded from our sample. Our sample includes 395 observations; it is unbalanced due to some missing data for provincial coal consumption and/or price, particularly early in the period. The main sources of data are the CEIC (2014), National Bureau of Statistics (2013), China Electricity Council (2013), and National Development and Reform Commission $(2011,2012)$. A full list of variable definitions and data sources is provided in the Appendix. Table 1 presents summary statistics.

The output price index for the mining and washing of coal in each province is the best coalprice measure we know of for the purpose of this study. The index captures coal price movements in a way that does not rely on averaging observed coal prices across different types of coal, which is advantageous given that provincial data on coal consumption by coal type are not available. Directly observed data on coal prices also have coverage challenges. ${ }^{6}$ Our approach assumes that changes in prices of coal mined and/or washed in each province are similar to changes in prices of coal imported by that province, based on the application of the economic principle of the "law of one price" at the province level. ${ }^{7}$ The coal price elasticity of demand may vary by sector, but we do not have data on sectoral purchase prices.

To obtain a coal price index in real terms, we deflate the nominal index by the provincial industrial producer price index. Results are similar using a coal price index that is not deflated or that is deflated with the provincial GDP deflator or the provincial consumer price index.

In an additional specification we use a proxy measure of the real coal price level (cf. index) in each province, calculated by multiplying (1) the average coal price paid by the electricity and heat sectors in each province in 2007 with (2) our time-varying index of coal prices in each province, and then deflating and logging. We calculated the average price in 2007 from China's provincial input-output tables for 2007. More details are in the Appendix.

\footnotetext{
${ }^{6}$ Cattaneo et al. (2011, p. 22) report that coal price data are "not available for China at (the) provincial level".

${ }^{7}$ While China's coal extraction is dominated by Inner Mongolia and Shanxi, most provinces extract and/or wash some coal. See the Appendix for details on how we treat the case of Shanghai.
} 
Table 1

Summary statistics.

\begin{tabular}{|c|c|c|c|c|c|}
\hline & Mean & $\begin{array}{l}\text { Standard } \\
\text { deviation }\end{array}$ & Minimum & Maximum & Missing \\
\hline Ln Coal consumption & 4.2 & 0.8 & 1.6 & 6.0 & 0 \\
\hline Ln Real coal price index & 4.1 & 0.4 & 2.8 & 4.8 & 0 \\
\hline Time trend & 7.4 & 4.2 & 0.0 & 14.0 & 0 \\
\hline Ln GDP & 8.8 & 0.9 & 6.0 & 10.9 & 0 \\
\hline Secondary share of economy $(\%)$ & 47.6 & 6.7 & 22.5 & 61.5 & 0 \\
\hline $\begin{array}{l}\text { State-owned share of total revenue from industrial } \\
\text { enterprises }(\%)\end{array}$ & 51.2 & 20.7 & 10.9 & 91.3 & 18 \\
\hline Five-year energy conservation assignments to industry (\%) & 2.0 & 2.3 & 0.0 & 8.9 & 0 \\
\hline Retired thermal power capacity $(\%)$ & 1.0 & 2.0 & 0.0 & 16.3 & 3 \\
\hline Ln Real gasoline price & 8.9 & 0.2 & 8.3 & 9.2 & 113 \\
\hline
\end{tabular}

Notes: Definitions, including units, are in the Appendix. 
In addition to challenges with coal price data, there are also issues surrounding data on coal consumption in China. The existence of small, unapproved coal mines means that coal data are less precise than data for other fossil fuels (Sinton, 2001) ${ }^{8}$ There is also evidence that local authorities have over-reported provincial coal use to be consistent with their overreported GDP (Ma et al., 2014). The central government's requirements for provinces to meet energy conservation targets and to close inefficient coal-fired electricity generators has, on the other hand, provided an incentive for some underreporting (Guan et al., 2012). While we control for provincial GDP, energy conservation targets, and power plant closures, as well as other factors that might be associated with data quality (such as provincial fixed effects), the results - like those from prior studies - need to be interpreted with serious data considerations in mind.

\section{Results}

Table 2 presents our results, with columns 1-4 providing static estimates and columns 5-9 including lagged coal price terms. The full-sample estimate in column 1 provides no evidence that provincial coal price movements are associated with provincial coal consumption, and we also find a statistically insignificant coal price elasticity in column 2 for a sample restricted to 1998-2007. Column 3 finds a coal price elasticity of -0.2 for 2008-2012, significantly different from zero at the 5\% level. These estimates suggest that coal consumption has become more responsive to prices in recent years.

Column 4 of Table 2 estimates Eq. (2) for the full sample. The interaction between the coal price variable and the time trend is negative and strongly significant, suggesting that the provincial coal price elasticity of demand has increased in absolute value. The estimate implies that this elasticity reached -0.4 in $2012\left(\beta_{1}+14 \beta_{4}\right)$, significantly different from zero at the $5 \%$ level.

Column 5 of Table 2 includes the price term in years $t-1$ and $t-2$, in addition to year $t$. The $t-$ 1 term is statistically insignificant, while the $t-2$ term is significantly different from zero at the $1 \%$ significance cut-off. The overall price elasticity of demand for the full period from this estimation is -0.1 , not significantly different from zero. To conserve degrees of freedom, we exclude the insignificant $t-1$ term from future estimations. Column 6 of Table 2 is the

\footnotetext{
${ }^{8}$ The closing of many informal coal mines in recent years has perhaps reduced this problem.
} 
same estimation as Column 5, but without the $t-1$ term. The coefficients on the other variables remain similar, and the mean two-year price elasticity $\left(\beta_{1}+\beta_{5}\right)$ remains not statistically different from zero in this full-sample estimate.

Columns 7-8 of Table 2 split the sample into the early (1998-2007) and late (2008-2012) periods. We find estimates of the two-year price elasticity of coal demand of 0 and -0.4 respectively, with the latter different from zero at the 5\% significance level. These results again suggest that provincial coal demand is becoming more price elastic. Column 9 interacts the two price terms with the time trend for the full sample and finds additional evidence that the two-year coal price elasticity of demand has indeed become larger over time, reaching 0.7 in 2012 (significant at 1\%). The implied price elasticity of demand is 0 in 1998, -0.2 (statistically indistinguishable from zero) in 2002, and -0.4 (significant at 1\%) in 2007. The point estimates of the income elasticity of coal use in Table 2 are larger than one (income elastic).

In the base of Table 2 we present the static and two-year price elasticities of coal demand for two additional specifications: using random effects (Specification 2); and using our log real price level measure instead of the log real price index in a pooled ordinary least squares (OLS) estimation (Specification 3). This latter estimate allows for geographical variation in coal prices as well as the temporal variation provided by the index. The random effects results are similar to our fixed effects specification, while the pooled OLS estimations provide larger price elasticity of demand point estimates. The results continue to suggest that the price elasticity of coal demand has increased over time, reaching -0.7 in 2012 when responses over two years are considered (and -0.55 when only same-year responses are included). Interestingly, coal price elasticity estimates for the full and early samples tend to be larger - and in some cases statistically significant - under pooled OLS, although timeinvariant variables affecting provincial coal demand have not been considered in these estimates. 
Table 2

Main results.

Dependent variable: Ln Coal consumption ${ }_{p, t}$

\begin{tabular}{|c|c|c|c|c|c|c|c|c|c|}
\hline & $(1)$ & $(2)$ & (3) & (4) & $(5)$ & $(6)$ & $(7)$ & $(8)$ & (9) \\
\hline Model & \multicolumn{4}{|c|}{ Static (columns 1-4) } & \multicolumn{5}{|c|}{ 2-year lag (columns 5-9) } \\
\hline Sample & Full & Early & Late & Full & Full & Full & Early & Late & Full \\
\hline Ln Real coal price index $x_{p, t}$ & $\begin{array}{l}-0.05 \\
(0.14)\end{array}$ & $\begin{array}{l}0.05 \\
(0.11)\end{array}$ & $\begin{array}{l}-0.23 * * \\
(0.10)\end{array}$ & $\begin{array}{l}0.04 \\
(0.14)\end{array}$ & $\begin{array}{l}0.13 * \\
(0.08)\end{array}$ & $\begin{array}{l}0.15 \\
(0.10)\end{array}$ & $\begin{array}{l}0.01 \\
(0.09)\end{array}$ & $\begin{array}{l}-0.21 * * \\
(0.09)\end{array}$ & $\begin{array}{l}0.06 \\
(0.14)\end{array}$ \\
\hline Ln Real coal price index $x_{p, t-1}$ & & & & & $\begin{array}{l}0.05 \\
(0.07)\end{array}$ & & & & \\
\hline Ln Real coal price index $x_{p, t-2}$ & & & & & $\begin{array}{l}-0.31 * * * \\
(0.07)\end{array}$ & $\begin{array}{l}-0.29 * * * \\
(0.09)\end{array}$ & $\begin{array}{l}-0.04 \\
(0.12)\end{array}$ & $\begin{array}{l}-0.19 * \\
(0.09)\end{array}$ & $\begin{array}{l}-0.01 \\
(0.18)\end{array}$ \\
\hline Ln Real coal price index ${ }_{p, t} *$ Time trend ${ }_{t}$ & & & & $\begin{array}{l}-0.03^{* * *} \\
(0.01)\end{array}$ & & & & & $\begin{array}{l}-0.03^{*} \\
(0.02)\end{array}$ \\
\hline Ln Real coal price index $x_{p, t-2} *$ Time trend $_{t}$ & & & & & & & & & $\begin{array}{l}-0.02 \\
(0.02)\end{array}$ \\
\hline $\operatorname{Ln} \operatorname{GDP}_{p, t}$ & $\begin{array}{l}1.20 * * * \\
(0.38)\end{array}$ & $\begin{array}{l}1.71 * * * \\
(0.26)\end{array}$ & $\begin{array}{l}1.30 * * \\
(0.53)\end{array}$ & $\begin{array}{l}1.49 * * * \\
(0.37)\end{array}$ & $\begin{array}{l}1.25 * * \\
(0.48)\end{array}$ & $\begin{array}{l}1.26 * * \\
(0.47)\end{array}$ & $\begin{array}{l}1.34 * * * \\
(0.46)\end{array}$ & $\begin{array}{l}1.29 * * \\
(0.48)\end{array}$ & $\begin{array}{l}1.37 * * * \\
(0.43)\end{array}$ \\
\hline Time trend $t$ & $\begin{array}{l}-0.04 \\
(0.04)\end{array}$ & $\begin{array}{l}-0.09 * * * \\
(0.03)\end{array}$ & $\begin{array}{l}-0.06 \\
(0.06)\end{array}$ & $\begin{array}{l}0.08 * \\
(0.04)\end{array}$ & $\begin{array}{l}-0.04 \\
(0.05)\end{array}$ & $\begin{array}{l}-0.04 \\
(0.05)\end{array}$ & $\begin{array}{l}-0.03 \\
(0.05)\end{array}$ & $\begin{array}{l}-0.04 \\
(0.06)\end{array}$ & $\begin{array}{l}0.18 * * \\
(0.06)\end{array}$ \\
\hline Province fixed effects & Yes & Yes & Yes & Yes & Yes & Yes & Yes & Yes & Yes \\
\hline$R^{2}$ (within) & 0.86 & 0.85 & 0.71 & 0.88 & 0.87 & 0.87 & 0.85 & 0.72 & 0.89 \\
\hline Observations & 395 & 255 & 140 & 395 & 336 & 336 & 196 & 140 & 336 \\
\hline Provinces & 30 & 30 & 28 & 30 & 30 & 30 & 30 & 28 & 30 \\
\hline \multirow[t]{2}{*}{ Price elasticity } & \multicolumn{4}{|c|}{ Columns 1-4: Static } & \multicolumn{5}{|c|}{ Columns 5-9: 2-year } \\
\hline & Mean & Mean & Mean & In 2012 & Mean & Mean & Mean & Mean & In 2012 \\
\hline Specification 1: As above & -0.05 & 0.05 & $-0.23 * *$ & $-0.44 * *$ & -0.13 & -0.14 & -0.03 & $-0.40 * *$ & $-0.68 * * *$ \\
\hline Specification 2: Random effects & -0.02 & 0.13 & $-0.20 *$ & $-0.33 * *$ & -0.09 & -0.09 & 0.04 & $-0.38 * *$ & $-0.63 * * *$ \\
\hline $\begin{array}{l}\text { Specification 3: Ordinary least squares, using } \\
\text { price level in place of price index }\end{array}$ & $-0.30 *$ & -0.21 & $-0.54 * *$ & $-0.55^{* *}$ & $-0.40 * *$ & $-0.40 * *$ & $-0.36 * *$ & $-0.54 * *$ & $-0.73 * * *$ \\
\hline
\end{tabular}

price level in place of price index

Notes: $* * * * *$, and $*$ indicate statistical significance at 1,5 , and $10 \%$. Standard errors, robust and clustered at the province level, shown in parentheses. Early: 1998-2007. Late: 2008-2012. Specification 3 excludes two provinces (Hainan and Qinghai). Coefficients on constants not reported. See Appendix for definitions. 
Cattaneo et al. (2011, p. 21) report "isolated clusters" of spatial dependence in their study of provincial coal use. As a robustness check on our results we repeated the estimation in column 9 of Table 2 six times, each time excluding one of China's regions (north; northeast; east; south-central; southwest; northwest). The results - available on request - are similar to our main results. Our estimates thus appear to be not driven by spatial dependence considerations within one region.

Table 3 presents fixed-effects results for estimates of Eq. (3) with additional controls. In column 2 we interact the log GDP variable with the time trend, finding no evidence that the income elasticity of coal use has changed over time. Columns 3-8 include the secondary share of the economy, state-owned share of revenue from industrial enterprises, energy conservation requirements, retirements of thermal power capacity, and the log real gasoline price. The price elasticities from these specifications and from static specifications are shown in the base of the table. We find an increasing price elasticity over time in each of the estimates, as shown by the negative coefficients for the price-time interaction terms. The twoyear price elasticity of coal demand, when assessed in 2012, is statistically significant, with estimates ranging from -0.5 to -0.7 . When assessed in 2007 , these estimates range from -0.2 to -0.4 . As of 2002, they were statistically inseparable from zero. For the static estimates, the year-2012 point elasticities range from -0.2 to -0.5 . It makes sense that these are smaller than the two-year price elasticities because the static estimates allow less time for coal consumers to respond to price changes.

The results on the controls in Table 3 are of interest. ${ }^{9}$ We find that a higher secondary share of the economy is associated with slightly more coal use, likely because industrial output is coal intensive. Specifically, a percentage-point increase in the secondary share of the economy is associated with $1 \%$ more coal consumption. The estimate in column 8 suggests that provinces that are more dependent on state-owned enterprises use slightly more coal. We find no significant effect of industrial energy conservation requirements or thermal plant retirements on provincial coal use. Columns $7-8$ suggest that gasoline and coal are complements in China, a finding also reported by Ma and Oxley (2012).

\footnotetext{
${ }^{9} \mathrm{We}$ obtain similar results also controlling for a measure of enterprise profits as a share of costs. Interaction terms with this measure provide no evidence that the province-level coal price elasticity of demand is systematically related to province-level enterprise profitability.
} 
Table 3

Results with additional controls.

Dependent variable: Ln Coal consumption $_{p, t}$

\begin{tabular}{|c|c|c|c|c|c|c|c|c|}
\hline & $(1)$ & $(2)$ & $(3)$ & $(4)$ & $(5)$ & $(6)$ & $(7)$ & $(8)$ \\
\hline Ln Real coal price index $x_{p, t}$ & $\begin{array}{l}0.06 \\
(0.14)\end{array}$ & $\begin{array}{l}0.05 \\
(0.15)\end{array}$ & $\begin{array}{l}0.12 \\
(0.14)\end{array}$ & $\begin{array}{l}0.06 \\
(0.14)\end{array}$ & $\begin{array}{l}0.03 \\
(0.16)\end{array}$ & $\begin{array}{l}0.05 \\
(0.14)\end{array}$ & $\begin{array}{l}0.44 * \\
(0.23)\end{array}$ & $\begin{array}{l}0.60 * * \\
(0.22)\end{array}$ \\
\hline Ln Real coal price index $x_{p, t-2}$ & $\begin{array}{l}-0.01 \\
(0.18)\end{array}$ & $\begin{array}{l}0.00 \\
(0.18)\end{array}$ & $\begin{array}{l}-0.06 \\
(0.16)\end{array}$ & $\begin{array}{l}-0.01 \\
(0.16)\end{array}$ & $\begin{array}{l}0.00 \\
(0.17)\end{array}$ & $\begin{array}{l}0.01 \\
(0.18)\end{array}$ & $\begin{array}{l}-0.17 \\
(0.23)\end{array}$ & $\begin{array}{l}-0.28 \\
(0.23)\end{array}$ \\
\hline Ln Real coal price index $x_{p, t} *$ Time trend $d_{t}$ & $\begin{array}{l}-0.03^{*} \\
(0.02)\end{array}$ & $\begin{array}{l}-0.03 * \\
(0.02)\end{array}$ & $\begin{array}{l}-0.03 * \\
(0.02)\end{array}$ & $\begin{array}{l}-0.03^{*} \\
(0.02)\end{array}$ & $\begin{array}{l}-0.03^{*} \\
(0.02)\end{array}$ & $\begin{array}{l}-0.03 * \\
(0.02)\end{array}$ & $\begin{array}{l}-0.06 * * * \\
(0.02)\end{array}$ & $\begin{array}{l}-0.07 * * * \\
(0.02)\end{array}$ \\
\hline Ln Real coal price index $x_{p, t-2} *$ Time trend ${ }_{t}$ & $\begin{array}{l}-0.02 \\
(0.02)\end{array}$ & $\begin{array}{l}-0.02 \\
(0.02)\end{array}$ & $\begin{array}{l}-0.01 \\
(0.01)\end{array}$ & $\begin{array}{l}-0.02 \\
(0.01)\end{array}$ & $\begin{array}{l}-0.02 \\
(0.02)\end{array}$ & $\begin{array}{l}-0.02 \\
(0.02)\end{array}$ & $\begin{array}{l}0.00 \\
(0.02)\end{array}$ & $\begin{array}{l}0.01 \\
(0.02)\end{array}$ \\
\hline $\operatorname{Ln} \operatorname{GDP}_{p, t}$ & $\begin{array}{l}1.37 * * * \\
(0.43)\end{array}$ & $\begin{array}{l}1.49 \text { *** } \\
(0.41)\end{array}$ & $\begin{array}{l}0.96 * * \\
(0.38)\end{array}$ & $\begin{array}{l}1.39 * * * \\
(0.42)\end{array}$ & $\begin{array}{l}1.40 * * * \\
(0.43)\end{array}$ & $\begin{array}{l}1.38 * * * \\
(0.43)\end{array}$ & $\begin{array}{l}1.32 * * * \\
(0.32)\end{array}$ & $\begin{array}{l}1.28 * * * \\
(0.32)\end{array}$ \\
\hline Time trend $d_{t}$ & $\begin{array}{l}0.18^{* *} \\
(0.06)\end{array}$ & $\begin{array}{l}0.21 * * * \\
(0.07)\end{array}$ & $\begin{array}{l}0.17 * * * \\
(0.06)\end{array}$ & $\begin{array}{l}0.18^{* *} \\
(0.07)\end{array}$ & $\begin{array}{l}0.18^{* *} \\
(0.06)\end{array}$ & $\begin{array}{l}0.19 \text { *** } \\
(0.07)\end{array}$ & $\begin{array}{l}0.22 * * * \\
(0.07)\end{array}$ & $\begin{array}{l}0.23 * * * \\
(0.07)\end{array}$ \\
\hline Ln $\operatorname{GDP}_{p, t} *$ Time trend $t$ & & $\begin{array}{l}-0.01 \\
(0.01)\end{array}$ & & & & & & \\
\hline Secondary share of economy $(\%)_{p, t}$ & & & $\begin{array}{l}0.01 * * \\
(0.00)\end{array}$ & & & & & $\begin{array}{l}0.01 * * \\
(0.00)\end{array}$ \\
\hline State-owned share of total revenue from industrial enterprises $(\%)_{p, t}$ & & & & $\begin{array}{l}0.00 \\
(0.00)\end{array}$ & & & & $\begin{array}{l}0.005^{*} \\
(0.003)\end{array}$ \\
\hline Post-2005 retired thermal power capacity $(\%)_{p, t}$ & & & & & & $\begin{array}{l}0.00 \\
(0.00)\end{array}$ & & $\begin{array}{l}0.00 \\
(0.00)\end{array}$ \\
\hline Ln Real gasoline price ${ }_{p, t}$ & & & & & & & $\begin{array}{l}-0.55^{* *} \\
(0.24)\end{array}$ & $\begin{array}{l}-0.56^{* *} \\
(0.23)\end{array}$ \\
\hline Province fixed effects & Yes & Yes & Yes & Yes & Yes & Yes & Yes & Yes \\
\hline Two-year price elasticity: & & & & & & & & \\
\hline Assessed at 2002 & -0.16 & -0.13 & -0.10 & -0.16 & -0.17 & -0.16 & 0.04 & 0.10 \\
\hline Assessed at 2007 & $-0.42 * * *$ & $-0.36 * *$ & $-0.31 * *$ & $-0.42 * * *$ & $-0.43 * * *$ & $-0.43 * * *$ & $-0.24 * *$ & -0.19 \\
\hline Assessed at 2012 & $-0.68 * * *$ & $-0.59 * * *$ & $-0.52 * * *$ & $-0.68 * * *$ & $-0.68 * * *$ & $-0.70 * * *$ & $-0.52 * * *$ & $-0.48 * * *$ \\
\hline Static price elasticity (assessed at 2012; regressions not shown) & $-0.44 * *$ & $-0.33^{*}$ & $-0.25^{*}$ & $-0.51 * * *$ & $-0.43 * *$ & $-0.45^{* *}$ & $-0.43 * * *$ & $-0.41 * *$ \\
\hline$R^{2}$ (within) & 0.89 & 0.89 & 0.89 & 0.89 & 0.89 & 0.89 & 0.87 & 0.88 \\
\hline Observations & 336 & 336 & 336 & 336 & 336 & 333 & 274 & 271 \\
\hline Provinces & 30 & 30 & 30 & 30 & 30 & 30 & 30 & 30 \\
\hline
\end{tabular}

Notes: $* * * * *$, and $*$ indicate statistical significance at 1,5 , and $10 \%$. Standard errors, robust and clustered at the province level, shown in parentheses. Coefficients on constants not reported. Years: 2000-2012. Column 1 is identical to Column 9 of Table 2. 
Table 4 shows estimates of Eq. (4) for specifications in one-year, two-year, three-year, fouryear, and five-year differences. Our sample shrinks as we move from an annual sample to a two-year differenced sample, and continues to do so across the columns of Table 4. In oneyear differences, the interaction between the coal price index measure and the time trend is negative and statistically significant at the $1 \%$ level, again indicating that the sensitivity of coal demand to coal prices has increased over time. The implied same-year coal price elasticity of demand in 2012 is -0.2 , whereas it is close to zero or even positive in early years of the panel.

Table 4

Estimations using differenced data.

Dependent variable: $\Delta_{x \text {-year }}$ Ln Coal consumption ${ }_{p, t}$

\begin{tabular}{|c|c|c|c|c|c|}
\hline & $(1)$ & $(2)$ & $(3)$ & $(4)$ & $(5)$ \\
\hline & $\begin{array}{l}x= \\
1\end{array}$ & 2 & 3 & 4 & 5 \\
\hline$\Delta_{x \text {-year }} \operatorname{Ln}$ Real coal price index $p, t$ & $\begin{array}{l}0.38 * * \\
(0.14)\end{array}$ & $\begin{array}{l}0.41 * * \\
(0.16)\end{array}$ & $\begin{array}{l}0.36 \\
(0.38)\end{array}$ & $\begin{array}{l}0.41 \\
(0.39)\end{array}$ & $\begin{array}{l}0.40 \\
(0.67)\end{array}$ \\
\hline$\Delta_{x \text {-year }} \operatorname{Ln} \operatorname{GDP}_{p, t}$ & $\begin{array}{l}1.60 * * * \\
(0.22)\end{array}$ & $\begin{array}{l}1.69 * * * \\
(0.28)\end{array}$ & $\begin{array}{l}1.46 * * * \\
(0.29)\end{array}$ & $\begin{array}{l}1.01 * * \\
(0.38)\end{array}$ & $\begin{array}{l}1.37 * * * \\
(0.36)\end{array}$ \\
\hline $\begin{array}{l}\Delta_{x \text {-year }} \text { Ln Real coal price } \\
\text { index }_{p, t} * \text { Time trend }_{t} \\
\text { Time trend } \\
\text { Time }\end{array}$ & $\begin{array}{l}-0.04 * * * \\
(0.01) \\
0.00 \\
(0.00)\end{array}$ & $\begin{array}{l}-0.05 * * * \\
(0.02) \\
0.00 \\
(0.00)\end{array}$ & $\begin{array}{l}-0.06 \\
(0.04) \\
-0.01 \\
(0.01)\end{array}$ & $\begin{array}{l}-0.05 \\
(0.05) \\
-0.01 \\
(0.02)\end{array}$ & $\begin{array}{l}-0.05 \\
(0.07) \\
-0.04 \\
(0.03)\end{array}$ \\
\hline \multicolumn{6}{|l|}{ Implied $x$-year price elasticity: } \\
\hline Assessed at 2002 & $0.21 * *$ & $0.22 *$ & 0.14 & 0.19 & 0.18 \\
\hline Assessed at 2007 & -0.01 & -0.03 & -0.14 & -0.08 & -0.10 \\
\hline Assessed at 2012 & $-0.22 * * *$ & $-0.28 * *$ & $-0.42 *$ & -0.34 & -0.37 \\
\hline$R^{2}$ & 0.18 & 0.25 & 0.21 & 0.19 & 0.46 \\
\hline Observations & 364 & 178 & 105 & 80 & 52 \\
\hline
\end{tabular}

The estimate in column 2 implies a two-year elasticity of -0.3 in 2012. The estimate in column 3 suggests the three-year elasticity was -0.4 in 2012, although this is only distinguishable from zero at the $10 \%$ significance level. The estimates in columns 4-5 provide similar point estimates of the regression coefficients, but it is not possible to conclude that price changes have a significant influence on coal use in these longerdifferenced specifications. These estimates are for relatively small samples, however. 
Altogether, the price elasticity estimates in Table 4 are consistent with our earlier results, suggesting that the two-year response of provincial coal use to provincial coal prices has become larger over time, although remains inelastic. Table 4's income elasticities are also similar.

\section{Relating the results to existing evidence}

There are only a few studies of the price elasticity of coal demand in China using subnational data. Ma and Oxley (2012) use provincial data for 1995-2005 to estimate translog cost functions, and derive estimates of the provincial coal price elasticity of demand of $-0.6-$ larger (in absolute value) than our estimates for those earlier years. Zhang et al. (2013) estimate a static model for 1995-2010 using coal output value divided by output volume as their measure of provincial coal prices. They surprisingly find a positive panel estimate of the price elasticity of coal demand, although they also obtain an elasticity of -0.3 in crosssectional estimates for 2010. Cattaneo et al. (2011) use a spatial econometric approach to model industrial use of coal by China's provinces, concentrating on income instead of price effects. Provincial data have been employed to model some other energy-sector issues in China, for example the relationship between GDP and $\mathrm{CO}_{2}$ emissions (Du et al., 2012) and the determinants of energy intensity (Jiang et al., 2014). Our study appears to be the first to explore whether the price elasticity of provincial demand for coal has changed over time.

Most studies of China's coal demand use annual time-series data for the nation as a whole, which necessarily involves estimation with a relatively small sample. Methods and results are mixed. Masih and Masih (1996) employ error-correction modelling for 1953-1992 and report a long-run price elasticity of coal demand near -1 . Chan and Lee (1997) use data for 19531990 and find point estimates of the long-run price elasticity of coal demand of -0.7 to -0.9 . Hang and Tu (2007) use data on the coal intensity of economic output for 1985-2005 and find a coal price elasticity of demand of -0.3 before 1995 and -1.6 after 1995. Lin et al. (2007) use an error correction model for 1980-2004 and find a long-run coal price demand elasticity of -0.3 , while Jiao et al. (2009) find a long-run coal price elasticity of demand of 1.2 for 1980-2006, also using error correction modelling. Kong (2010) finds a price elasticity of coal demand of -0.1 to -0.2 for 1978-2007; Lin and Jiang (2011) a coal price elasticity of demand for China's electricity sector of -0.5 ; and Zhang et al. (2011) a statistically insignificant coal price elasticity of demand for 1978-2008. An advantage of our use of panel 
data is that our sample is larger than those used in these time-series studies. We are also able to control for time-invariant factors affecting coal demand.

Studies for other countries and regions, including the United States and Europe, have also reported that demand for coal is price inelastic. Short-run estimates of this price elasticity typically fall in the range -0.1 to -0.6 (see Table 5 of Trüby and Paulus, 2012). Coady et al. (2015) used a coal price elasticity of demand of -0.25 in their recent high-profile study of the effects of international fossil fuel subsidy reform.

Our Table 2 estimates of the income elasticity of coal demand range from 1.2-1.7. These are high, consistent with the rapid expansion of coal use in China. Note, however, that our use of a linear time trend removes the effect of secular changes in coal use per unit output over time. In specifications without a time trend, we obtain income elasticities of 0.8 , similar to those obtained by Chan and Lee (1997) and Lin et al. (2007). Other estimates of the income elasticity of coal demand by China's provinces range from 0.2 (Cattaneo et al., 2011) to 1.1 (Masih and Masih, 1996).

\section{Conclusion}

China has a target to reduce the $\mathrm{CO}_{2}$ intensity of its economy by $40-45 \%$ from its 2005 level by 2020 , and is currently running emissions trading pilot schemes for greenhouse gases. A carbon tax is also being considered (Jotzo and Löschel, 2014). For pricing schemes to reduce emissions, it is important that coal use is responsive to prices. China's coal sector has increasingly marketized over recent years, and we hypothesized that this may have contributed to more price-elastic coal demand.

We have utilized provincial data and obtained evidence that coal use in China is indeed becoming increasingly sensitive to coal prices. Our estimates suggest that, as of 2012, a $1 \%$ increase in coal prices typically resulted in a reduction in the quantity of coal demanded of $0.3-0.7 \%$. This is an inelastic response, but nevertheless indicates that emissions pricing could bring material reductions in emissions from coal.

Our results are similar using a variety of controls and in both level and differenced regressions. Nevertheless, the reader is reminded that there are uncertainties associated with coal use data in China. There may also be important differences in the price elasticity of 
demand for different coal products and uses. Our results - like those from prior studies should be interpreted as suggestive rather than definitive. Rapid changes to China's energy sector also mean that the price elasticity of coal demand may continue to evolve. Continued research into this topic will thus be of interest.

In addition to ongoing marketization, there are other potential explanations for why China's provincial-level price elasticity of demand for coal is increasing. One is that in recent years there have been more substitutes for coal, including nuclear power, natural gas, and renewables. A second is that the rapid increase in coal prices over much of our study period has fed into a higher coal price elasticity of demand; in general, higher prices may be associated with greater sensitivity to proportional price changes (Burke and Nishitateno, 2013).

The IEA (2013) estimates that in 2012 China allocated $\$ 13$ billion to price subsidies for the consumption of coal ( $\$ 3$ billion) and the use of coal for electricity generation ( $\$ 10$ billion). Our rough estimate is that removing these subsidies would increase average coal prices in China by around $3 \% .{ }^{10}$ Using a coal price elasticity of demand of -0.6 , this would result in around a $2 \%$ reduction in China's annual $\mathrm{CO}_{2}$ emissions from coal. $2 \%$ is rather a lot; equal to more than three-quarters of Australia's annual $\mathrm{CO}_{2}$ emissions from coal (IEA, 2014b). As well as providing fiscal and efficiency benefits, the elimination of coal subsidies could thus lead to a material reduction in China's $\mathrm{CO}_{2}$ and other emissions relative to the counterfactual in which the subsidies are retained. The above calculation is quite similar to Li and Lin's (2015) estimate of a 3\% reduction in China's energy-based $\mathrm{CO}_{2}$ emissions if all fossil fuel subsidies were removed.

One ongoing challenge for China's energy market is the lack of a mechanism to allow retail electricity prices to vary with changes in input prices, including the coal price (IEA and

\footnotetext{
${ }^{10} \mathrm{We}$ calculate the average coal price subsidy in 2012 at 24 yuan/tonne of coal by dividing the $\$ 13$ billion IEA (2013) estimate of China's consumption subsidies for coal by China's coal consumption in 2012 (3.5 billion tonnes; CEIC, 2014), and applying the average official exchange rate for 2012 of 6.3 yuan/\$US from the World Bank (2014). We then divide the average coal price subsidy by China's year-2012 average coal contract price for power generation as reported by the Lawrence Berkeley National Laboratory (2014). This is an approximate calculation. We obtain a similar result if we use an alternative price measure, for example the FOB Qinhuangdao price for steam coal imports (Q5500K).
} 
Energy Resource Institute, 2012). Regulated electricity prices continue to place electricity generators and grid companies in difficult financial positions, as they cannot easily pass cost changes through to consumers. The phase-out of consumer subsidies for coal and electricity and a move to more flexible pricing arrangements for electricity would help to further improve the efficiency of energy use in China and increase the country's readiness for market-based approaches to reducing emissions. 


\section{References}

Baltagi, B.H. (2008). Econometric Analysis of Panel Data. $4^{\text {th }}$ ed. West Sussex, UK: John Wiley \& Sons.

BP (2014). Statistical Review of World Energy 2014.

http://www.bp.com/en/global/corporate/about-bp/energy-economics/statistical-review-ofworld-energy.html.

Burke, P.J., \& Nishitateno, S. (2013). Gasoline prices, gasoline consumption, and newvehicle fuel economy: Evidence for a large sample of countries. Energy Economics, 36, 363 370 .

Cattaneo, C., Manera, M., \& Scarpa, E. (2011). Industrial coal demand in China: A provincial analysis. Resource and Energy Economics, 33(1), 12-35.

CEIC (2014). CEIC Database. http://www.ceicdata.com/.

Chan, H.L., \& Lee, S.K. (1997). Modelling and forecasting the demand for coal in China. Energy Economics, 19(3), 271-287.

China Daily (2007). China to further deregulate coal prices in 2008. China Daily, 26 November, http://www.chinadaily.com.cn/bizchina/2007-11/26/content_6279544.htm.

China Electricity Council (2013). Compilation of China's Power Industrial Statistics. Beijing. Earlier editions also utilized.

Chu, T., Fesharaki, F., \& Wu, K. (2006). China's energy in transition: Regional and global implications. Asian Economic Policy Review, 1(1), 134-152.

Coady, D., Parry, I., Sears, L., \& Shang, B. (2015). How large are global energy subsidies? IMF Working Paper WP/15/105.

Du, L., Wei, C., \& Cai, S. (2012). Economic development and carbon dioxide emissions in China: Provincial panel data analysis. China Economic Review, 23(2), 371-384.

Economist (The) (2011). China's coal: Central planning takes a black eye. The Economist, 24 January.

Guan, D., Liu, Z., Geng, Y., Lindner, S., \& Hubacek, K. (2012). The gigatonne gap in China's carbon dioxide inventories. Nature Climate Change, 2, 672-675.

Hang, L., \& Tu, M. (2007). The impacts of energy prices on energy intensity: Evidence from China. Energy Policy, 35(5), 2978-2988.

Im, K.S., Pesaran, M.H., \& Shin, Y. (2003). Testing for unit roots in heterogeneous panels. Journal of Econometrics, 115(1), 53-74.

International Energy Agency (2009). Cleaner Coal in China. Paris: International Energy Agency. 
International Energy Agency (2013). World Energy Outlook 2013. Paris: International Energy Agency.

International Energy Agency (2014a). World Energy Outlook 2014. Paris: International Energy Agency.

International Energy Agency (2014b). $\mathrm{CO}_{2}$ Emissions from Fuel Combustion. Paris: International Energy Agency.

International Energy Agency (2015). World Energy Statistics and Balances. Paris: International Energy Agency.

International Energy Agency and Energy Research Institute (2012). Policy Options for LowCarbon Power Generation in China: Designing an Emissions Trading System for China's Electricity Sector. Paris.

Jiang, L., Folmer, H., \& Ji, M. (2014). The drivers of energy intensity in China: A spatial panel data approach. China Economic Review, 31, 351-360.

Jiao, J.-L., Fan, Y., \& Wei, Y.-M. (2009). The structural break and elasticity of coal demand in China: empirical findings from 1980-2006. International Journal of Global Energy Issues, 31(3/4), 331-344.

Jotzo, F., \& Löschel, A. (2014). Emissions trading in China: Emerging experiences and international lessons. Energy Policy, 75, 3-8.

Kong, X. (2010). An empirical analysis on the dynamic relationships between coal consumption and its influential factors in China: Asymmetric effects of price on coal consumption. Resources Science, 32, 1830-1838. (In Chinese).

Lawrence Berkeley National Laboratory (2014). Key China Energy Statistics 2014. Berkeley: Lawrence Berkeley National Laboratory.

Li, C. (2014). Coal negotiations are still deadlocked. Securities Daily, 7 January, http://zqrb.ccstock.cn/html/2014-01/07/content_394771.htm. (In Chinese).

Li, K., \& Lin, B. (2015). How does administrative pricing affect energy consumption and $\mathrm{CO}_{2}$ emissions in China? Renewable and Sustainable Energy Reviews, 42, 952-962.

Lin, B., \& Jiang, Z. (2011). Estimates of energy subsidies in China and impact of energy subsidy reform. Energy Economics, 33(2), 273-283.

Lin, B., Wei, W., \& Li, P. (2007). China's long-run coal demand: impacts and policy choice. Economic Research Journal, 42, 48-58. (In Chinese).

Lin, C.-Y.C., \& Zeng, J. (2013). The elasticity of demand for gasoline in China. Energy Policy, 59, 189-197.

Ma, B., Song, G., Zhang, L., \& Sonnenfeld, D.A. (2014). Explaining sectoral discrepancies between national and provincial statistics in China. China Economic Review, 30, 353-369. 
Ma, H., \& Oxley, L. (2011). Are China's energy markets cointegrated? China Economic Review, 22, 398-407.

Ma, H., \& Oxley, L. (2012). China's Energy Economy: Situation, Reforms, Behavior, and Energy Intensity. Heidelberg: Springer.

Ma, H., Oxley, L., \& Gibson, K. (2009). China's energy situation in the new millennium. Renewable and Sustainable Energy Reviews, 13(8), 1781-1799.

Masih, R., \& Masih, A.M.M. (1996). Stock-Watson dynamic OLS (DOLS) and errorcorrection modelling approaches to estimating long- and short-run elasticities in a demand function: new evidence and methodological implications from an application to the demand for coal in mainland China. Energy Economics, 18(4), 315-334.

Mischke, P., \& Karlsson, K.B. (2014). Modelling tools to evaluate China's future energy system - A review of the Chinese perspective. Energy, 69, 132-143.

National Bureau of Statistics (2008). China Energy Statistical Yearbook 2007. Beijing: China Statistical Press.

National Bureau of Statistics (2011). China Region Input-Output Tables 2007. Beijing: China Statistical Press.

National Bureau of Statistics (2013). China Urban Life and Price Yearbook. Beijing: China Statistical Press. Data from earlier issues also used.

National Bureau of Statistics (2014). China Statistical Database. Beijing.

National Development and Reform Commission (2011). Targets and Achievements of 1,000 Enterprises Energy Conservation Campaign. Beijing.

National Development and Reform Commission (2012). Targets and Achievements of 10,000 Enterprises Energy Conservation Campaign. Beijing.

Reuters (2015). China 2014 coal output seen down 2.5 pct, first drop in a decade. 28 January, http://www.reuters.com/article/2015/01/29/china-economy-output-coalidUSL4NOUZ3PO20150129.

Rutkowski, R. (2013). The price of power: the new Chinese leadership begins rebalancing with resource prices. China Economic Watch, http://www.piie.com/blogs/china/?p=2913.

Sinton, J.E. (2001). Accuracy and reliability of China's energy statistics. China Economic Review, 12(4), 373-383.

Thomson, E. (2003). The Chinese Coal Industry: An Economic History. London: Routledge Curzon.

Trüby, J., \& Paulus, M. (2012). Market structure scenarios in international steam coal trade. Energy Journal, 33(3), 91-123. 
Wind Information (2015). Wind Economic Terminal. http://www.wind.com.cn/en/.

Wang, B. (2007). An imbalanced development of coal and electricity industries in China. Energy Policy, 35(10), 4959-4968.

Wong, E. (2013). Air pollution linked to 1.2 million premature deaths in China. New York Times, 1 April.

World Bank (2014). World Development Indicators. http://data.worldbank.org/datacatalog/world-development-indicators.

Wright, T. (2000). The political economy of prices in China's planned and market economies: competition and control in the coal industry. Asian Studies Review, 24(3), 349376.

Wright, T. (2012). The Political Economy of the Chinese Coal Industry: Black Gold and Blood-Stained Coal. New York: Routledge.

Xiao, X., \& Wu, L. (2011). The evolution of the pricing mechanism for heavy industrial products during 1949-1978. Researches in Chinese Economic History, 3, 85-95. (In Chinese).

Yang, C.-J., Xuan, X., \& Jackson, R.B. (2012). China's coal price disturbances:

Observations, explanations, and implications for global energy economies. Energy Policy, 51, 720-727.

Yue, F. (2007). Coal cost composition issues and their solutions. Macroeconomic Research, 27, 49-57. (In Chinese).

Zhang, K., Wang, J., \& Huang, Y. (2011). Estimating the effect of carbon tax on $\mathrm{CO}_{2}$ emissions of coal in China. Journal of Environmental Protection, 2(8), 1101-1107.

Zhang, L., Han, M., \& Dahl, C.A., (2013). Estimation of coal demand elasticities in China: Time volatility and regional differences. Resources Science, 35, 1977-1983. (In Chinese).

Zhang, N., (2012). The game of the integration of coal pricing. Energy, 11, http://media.hexun.com/2012/ny20121102/. (In Chinese).

Zhang, Z. (2014). Energy prices, subsidies and resource tax reform in China. Asia \& the Pacific Policy Studies, 1(3), 439-454.

Zhao, Z., Song, T., \& Fan S. (2012). Market oriented reforms to China's coal pricing mechanism. Price Theory \& Practice, 9, 30-31. (In Chinese). 


\section{Appendix: Variable descriptions}

Ln Coal consumption: Natural logarithm of total primary coal consumption, in million tonnes. Source: CEIC (2014).

Ln Real coal price index: Natural logarithm of: the output price index for the mining and washing of coal, deflated by the provincial industrial producer price index. A coal price index for Shanghai is not available; we have used data for Zhejiang (a neighbouring province) instead. Source: National Bureau of Statistics (2013) and various provincial Statistical Yearbooks. Industrial producer price index data are from the National Bureau of Statistics (2014).

Ln Real coal price level: Natural logarithm of: the product of each province's year-2007 coal price for the thermal sector and each province's coal price index, deflated by the provincial industrial producer price index. The year-2007 coal price for the thermal sector, in yuan per tonne, is calculated by dividing (1) each province's thermal sector's expenditure on intermediate inputs from the coal sector and its transportation by (2) the coal consumption of the thermal sector. Two provinces (Hainan and Qinghai) are excluded from these estimations. The thermal sector consists of electricity and heat generation. Source: National Bureau of Statistics $(2008,2011)$.

Time trend: Linear time trend. Equal to 0 in 1998 and 14 in 2012.

Ln GDP: Natural logarithm of gross domestic product in real $10^{8}$ yuan (2012 prices). Source: CEIC (2014).

Secondary share of economy (\%): The percentage share of total value added contributed by secondary industry. Source: National Bureau of Statistics (2014).

State-owned share of total revenue from industrial enterprises (\%): Revenue of state-owned and state holding industrial enterprises as a percentage of the revenue of all industrial enterprises. For the period 1998-2006 the variable covers all state-owned enterprises as well as all other enterprises with principal-business revenue over 5 million yuan; for 2007-2010 the variable covers all enterprises with principal-business revenue over 5 million yuan. Since 
2011, the variable covers all enterprises with principal-business revenue over 20 million yuan. Source: National Bureau of Statistics (2014).

Five-year energy conservation assignments to industry (\%): Sum of all energy conservation assignments to individual enterprises over a five-year period (1,000 Enterprises Energy Conservation Campaign of 2006-2010; 10,000 Enterprises Energy Conservation Campaign of 2011-2015) as a percentage of total energy consumption in the first year of the five-year period (2006 or 2011). 0 for years prior to 2006 because it was only after this year that the central government placed greater priority on energy conservation. Source: National Development and Reform Commission (2011, 2012).

Post-2005 retired thermal power capacity (\%): Retired thermal power capacity in megawatts as a percentage of the start-of-year thermal capacity; $=0$ for years prior to 2006 because it was only after this year that the central government placed greater priority on energy conservation. China Electricity Council (2013).

Ln Real gasoline price: Natural logarithm of the average price for no. 93 gasoline (without lead) in the province's capital city, deflated by the provincial industrial producer price index. Price data based on average across monthly prices. Source: CEIC (2014). Industrial producer price index data from the National Bureau of Statistics (2014). 